\title{
Settlement Sovereignty: The Meskwaki Fight for Self-Governance, 1856-1937
}

\author{
ERIC STEVEN ZIMMER
}

ON NOVEMBER 17, 1937, an official at the Office of Indian Affairs (OIA) in Washington, D.C., wired a brief, fragmented note to the superintendent at the Tama Indian Agency in central Iowa: "Congratulations to you and Indians results Iowa constitution election." 1 The message's hurried, celebratory tone came in response to news the OIA had received a day earlier: members of the Meskwaki tribe had accepted, by an excruciatingly narrow two-vote margin, a constitution in accordance with the provisions of the Indian Reorganization Act of 1934 (IRA). Less than a month later, a message from several Meskwaki men about the same event arrived on the desk of the U.S. Secretary of the Interior. This petition took a far different tone: "We members of the Sac and Fox Indians at Tama Iowa are not satisfied with the election

This article would not have been possible without funding from the University of Iowa (UI) Graduate Student Senate and a State Historical Society of Iowa Research Grant. The author presented drafts at UI history department conferences in 2012 and 2013 and at the Native American and Indigenous Studies Association annual meeting in 2013. Many thanks go out to all of the readers, known and anonymous, who offered comments - especially Jacki Thompson Rand, Johnathan and Suzanne Buffalo, Douglas Foley, and Mary Bennett. The article is dedicated, with love, to Samantha, who married me just as it came off the press. 1. William Zimmerman Jr. to Ira D. Nelson, 11/17/1937, IRA folder, Meskwaki Historic Preservation Department and Museum, Tama, Iowa (hereafter IRAMHPDM). For further information, see Judith Daubenmier, The Meskwaki and Anthropologists: Action Anthropology Reconsidered (Lincoln, NE, 2008), 45; and Theodore H. Haas, Ten Years of Tribal Government under I.R.A. (Lawrence, KS, 1947), 16-26. The Office of Indian Affairs became the Bureau of Indian Affairs in 1947. This article uses the historically accurate former term throughout. 
that was recently supposed to be held, which was supposed to adopt a mode of handling the Indian lands that belong to us." It came affixed with nearly a hundred Meskwaki signatures. ${ }^{2}$

These pieces of correspondence reveal the controversy surrounding a tribal legal transformation that had been brewing on the settlement for over three years. Since early 1934 Meskwaki tribal members had been considering the ramifications of the IRA, the most significant legislative change in Indian policy during the so-called Indian New Deal. That dramatic shift in federal policy presented tribes nationwide with a choice between retaining long-held forms of government and organizing under a constitution that purported to reaffirm tribal self-governance after several oppressive and assimilative decades. Despite a contentious debate over the IRA and the language its constitution would ultimately take, the tribe officially reorganized in the autumn of 1937.3

The ratification that fall marks a pivotal moment in the transformation of Meskwaki governance. The document recast the tribal government, and the Meskwaki Nation follows it to this day. This article surveys the years between 1856 and 1937, offering a case study of the ways American Indian communities have acted throughout history to affirm their tribal sovereignty. Meskwaki political maneuvering during this period-which included the leveraging of their unique land ownership-exposes weaknesses in the oppressive project of assimilation carried out by the OIA in the nineteenth and early twentieth centuries. Despite its best efforts, the agency failed to snuff out the Meskwaki ability to engage their politics and control local affairs. Instead, tribal members

2. John Tataposh et al. to Harold L. Ickes, 12/13/1937, IRA-MHPDM. The Meskwaki Nation is formally recognized as the "Sac and Fox of the Mississippi in Iowa." Meskwaki roughly translates to "Red Earth People" and represents the tribal spelling. It is one of three tribes bearing the name "Sac and Fox," a title that derives from the close historical association between the Meskwaki and the Sauk. The two others are the Sac and Fox Nation in Oklahoma and the Sac and Fox Nation of Missouri in Kansas and Nebraska. See L. Edward Purcell: "The Unknown Past: Sources for History Education and the Indians of Iowa," in The Worlds Between Two Rivers: Perspectives on American Indians in Iowa, ed. Gretchen M. Bataille, David M. Gradwohl, and Charles L. P. Silet (Ames, 1978), 27.

3. Johnathan L. Buffalo, "Historical Overview of the Adoption of the Indian Reorganization Act of 1934 by the Sac and Fox of the Mississippi in Iowa," 30-33, IRA-MHPDM. 
persistently dodged attacks on their sovereignty and negotiated internally to maintain, and ultimately reshape, their government.

Historians of Native America have been pushing back against monolithic and declensionist narratives of Indian history for several decades. Yet many Americans remain familiar with wellworn stories that frame the removal and relegation of Native peoples to federally assigned lands as an easy, straightforward process disrupted only when famous leaders like Crazy Horse and Geronimo led violent resistance movements. As bloody, destructive, and oppressive as the Native encounter with the expanding American nation often was, tribal peoples were not just militant warriors or passive players in a generally swift and easy conquest. As Frederick E. Hoxie observes, "Native people spent far more time negotiating, lobbying, and debating than they spent tomahawking settlers or shooting soldiers." 4

The Meskwaki story is one among many that reveal how tribal efforts to work against the pressures of colonialism and assert the tribe's sovereignty extend deep into the past and took myriad forms. ${ }^{5} \mathrm{C}$. Joseph Genetin-Pilawa has shown how, in the late nineteenth and early twentieth centuries, the development of federal Indian policies like allotment-though long considered neat and almost automatic - were in reality hard-fought and highly contingent. ${ }^{6}$ The Meskwaki story similarly diverges from standard narratives of Native history. It exposes weaknesses in the fortress of American colonialism by showing how a small tribe that owned its

4. Frederick E. Hoxie, This Indian Country: American Indian Activists and the Place They Made (New York, 2012), 4.

5. See Charles F. Wilkinson, Blood Struggle: The Rise of Modern Indian Nations (New York, 2005), 188-204; and George Pierre Castile, Taking Charge: Native American Self-Determination and Federal Indian Policy, 1975-1999 (Tucson, AZ, 2006). Several authors have recognized Meskwaki persistence as a unifying historical theme. See, for example, R. David Edmunds and Joseph L. Peyser, The Fox Wars: The Mesquakie Challenge to New France (Norman, OK, 1993), xvii-xviii. For discussions of sovereignty, self-determination, and self-governance, see Joanne Barker, "For Whom Sovereignty Matters," and Taiaiake Alfred, "Sovereignty," both in Sovereignty Matters: Locations of Contestation and Possibility in Indigenous Struggles for Self-Determination, ed. Joanne Barker (Lincoln, NE, 2005); and Susan A. Miller, "Native Historians Write Back: The Indigenous Paradigm in American Indian Historiography," Wicaso Sa Review 24 (2009), 32.

6. See C. Joseph Genetin-Pilawa, Crooked Paths to Allotment: The Fight over Federal Indian Policy after the Civil War (Chapel Hill, NC, 2012). 
land carved a unique path through the policies of assimilation and allotment and fought to reform its government on its own terms.

This article follows in the footsteps of those scholars who have recently uncovered tribal strategies to work within and around their precarious relationship to the U.S. government over the past two hundred years. ${ }^{7}$ It emphasizes tribal-federal relations but makes a few cursory nods to state-tribal politics - a subject to be expanded upon in future research. In the 1850s a contingent of tribal members returned to Iowa and joined some Meskwaki who never left the state. In 1857 they purchased an 80-acre "settlement," upon which tribal members subsisted and repelled federal incursions into their economic, political, and social practices until the State of Iowa transferred the land into federal trust in 1896. Thereafter, the OIA exploited a political rift within the tribe, which, over time, the agency used to weaken Meskwaki sovereignty and slowly erode tribal control over its governance. Even as their political power withered, tribal members continued to participate in local, and later national, politics. Meskwaki people organized around several key issues, made their voices heard, and influenced the outcomes of various disputes with local administrators. The Meskwaki encounter with the Indian New Deal of the 1930s shows how political developments in preceding decades shaped tribal responses to the IRA and, ultimately, how the tribe recast its government in 1937. ${ }^{8}$ Although this essay ends with the ratification of the constitution, debates over its ramifications for Meskwaki governance, as well as the tribe's sovereign struggle, continue today.

THE MESKWAKI NATION holds a unique distinction in the history of Native America: it was the first tribe to purchase its land after the era of Indian removal in the mid-nineteenth

7. See, for example, Kevin Bruyneel, The Third Space of Sovereignty: The Postcolonial Politics of U.S.-Indigenous Relations (Minneapolis, 2007); David R. M. Beck, The Struggle for Self-Determination: History of the Menominee Indians since 1854 (Lincoln, NE, 2005); and Valerie Lambert, Choctaw Nation: A Story of American Indian Resurgence (Lincoln, NE, 2007).

8. Indian Reorganization Act of 1934 (6/18/1934), 984-88; and Constitution and ByLaws of the Sac and Fox Tribe of the Mississippi in Iowa (Washington, DC, 1938). The constitution can be viewed in full at www.meskwaki.org/trcode.html, accessed 3/24/2013. 
century. ${ }^{9}$ In 1857 the Meskwaki sidestepped the assignment of Indian tribes to federal reservations by working directly with the State of Iowa. In the 1840s most Meskwaki had been removed to the Indian Territory in present-day Kansas, which many tribal members despised because of its arid, treeless environment and sparse game. A small contingent returned to their homelands along the Iowa River, joining some Meskwaki who had never left. The Iowa legislature formally approved Meskwaki residency in an 1856 law, and the following year, the tribe purchased the 80acre "settlement" through an agreement with the governor. The settlement is not a "reservation," as Indian lands are often called, because, although its legal status has changed over time, the tribe purchased and still owns the settlement communally. The State of Iowa held the settlement in trust on the condition that the Meskwaki paid property taxes and abided by state laws. ${ }^{10}$

For the duration of the nineteenth century, Meskwaki tribal members adhered to their customary economic, political, and cultural practices. They subsisted by hunting, gardening, and occasionally trading with locals and regional tribes, and continued to practice their clan/bundle-based religion and ceremonies. ${ }^{11}$

9. I offer this claim tentatively. There are 566 federally recognized American Indian nations in the United States today and some 400 unrecognized Indian groups. Many communities have unique landed histories, wherein title has been passed down from colonial land grants or through treaties, among other scenarios. Moreover, land purchase has become a common practice in recent decades. The Jamestown S'Klallam of present-day Washington State purchased their land several decades after the Meskwaki. See Joseph H. Stauss, The Jamestown S'Klallam Story: Rebuilding a Northwest Coast Indian Tribe (Sequim, WA, 2002).

10. For a detailed account of Meskwaki history in the 1840s and 1850s, see Michael D. Green, "'We Dance in Opposite Directions': Mesquakie (Fox) Separatism from the Sax and Fox Tribe," Ethnohistory 3 (1983), 129-40. See also Stephen Warren, “'To Show the Public We Were Good Indians': Origins and Meanings of the Meskwaki Powwow," American Indian Culture and Research Journal 33 (2009), 4-5; Richard Frank Brown, "A Social History of the Mesquakie Indians, 1800-1963" (M.A. thesis, Iowa State University, 1964), 56-57; Natalie F. Joffe, "The Fox of Iowa," in Acculturation in Seven American Indian Tribes, ed. Ralph Linton (London, 1940), 288-29; and Daubenmier, Meskwaki and Anthropologists, 32-33. 11. Joffe, "Fox of Iowa," 263-64; U.S. Indian Agent Thomas S. Free, "Agency of the Sac and Fox Indians in Iowa," in U.S. Office of Indian Affairs, Annual Report of the Commissioner of Indian Affairs to the Secretary of the Interior, 1875 (Washington, DC, 1875), 290-91; Leander Clark, "Sacs and Foxes in Iowa," in U.S. Office of Indian Affairs, Report of the Commissioner of Indian Affairs, 1868 (Washington, DC, 1868), 307, quoted in Johnathan Buffalo, "1846-1856: The Iowa Journey," 
Tribal members handled internal affairs as they had for centuries. In keeping with the tribe's egalitarian values, leaders, who were drawn from kin-based clans, exerted influence "by force of personality" rather than the innate power of their chieftainship. Even "the [head] chief, for all of his imputed authority, was primarily the spokesman for the tribe, and his power was directive, not coercive." 12

The Meskwaki conducted political affairs communally and went into council when decisions on specific "business of the moment [needed to be] transacted." The council normally met on four occasions each year - "at corn-planting, mid-summer, [at the] first frost, and mid-winter" - but also gathered when important issues arose. Meetings lasted for up to four days, and all adult Meskwaki "voted" by offering opinions to clan leaders outside the council. Women, wrote one observer, did not directly "engage men in public debate," and decorum precluded them from speaking during council. Nevertheless, Meskwaki women often met outside the council, developed a group opinion, and pressed the men of their respective households to share their position. That practice earned Meskwaki women a reputation for "turning public opinion this way or that." Nevertheless, only council members were involved in the final decision-making process. Generally speaking, tribal members respected and adhered to these consensual decisions. ${ }^{13}$

The importance of the state's role in facilitating the Meskwaki land purchase, as well as its non-intrusive policy toward the tribe until 1896, cannot be overstated. Since the earliest years of the republic, states have exploited the decentralized nature of American federalism - that is, the ambiguity over which practices fall under

Meskwaki History CD-ROM, ed. Johnathan Buffalo, Dawn Suzanne Wanatee, and Mary Bennett (Iowa City, IA, 2006).

12. Buffalo, "Historical Overview," 1. For more on customary Meskwaki governance, see Edmunds and Peyser, Fox Wars, 37; Nancy Bonvillain, The Sac and Fox (New York, 1995), 30-33; and Joffe, "Fox of Iowa," 271.

13. Oxford Weekly Leader, 8/7/1869; Mary Alicia Owen, Folk-Lore of the Musquakie Indians of North America (London, 1904), 26, 33; Buffalo, "Historical Overview," 1-2; U.S. Indian Agent W. L. Lesser, "Report of the Agent in Iowa, Report of the Sac and Fox Agency, Iowa," in U.S. Office of Indian Affairs, Fifty-Ninth Annual Report of the Commissioner of Indian Affairs to the Secretary of the Interior, 1890 (Washington, DC, 1890), 103-6. 
the purview of either the federal government or a given statein order to conduct a "gradual local assertion of direct rule over Indians." 14 Unlike many other states, whose policies often harmed Native communities, Iowa maintained a policy that treated the Meskwaki paternalistically but was otherwise benign throughout the late nineteenth century. The state made no efforts to alter the settlement agreement or to interfere with Meskwaki self-governance for almost 40 years, most likely because of the tribe's rural location and peaceful but limited contact with white settlers. ${ }^{15}$ As L. Edward Purcell writes, successive Iowa governors "seemed to regard seriously the trust placed upon them for the well-being of the tribe." 16 They not only refused to undo the tribe's trust relationship, but acted as intermediaries. Tribal leaders frequently contacted the governor's office for support when federal officials carried out policies with which the tribe disagreed, and a cooperative relationship developed between the Meskwaki and the state. ${ }^{17}$ Iowa's acceptance of Meskwaki residency allowed tribal members to stabilize and reunify their community after two disjunctive decades, and the roughly 250 Meskwaki remained selfsufficient and self-governing through an era infamous for the repression of Native peoples. ${ }^{18}$

14. Deborah A. Rosen, American Indians and State Law: Sovereignty, Race, and Citizenship, 1790-1880 (Lincoln, NE, 2007), xi.

15. U.S. Indian Agent Leander Clark, "Sacs and Foxes in Iowa," in Message of the President of the United States and Accompanying Documents to the Two Houses of Congress at the Commencement of the Second Session of the Fortieth Congress, 1867 (Washington, DC, 1867), 25-26. On the Meskwakis' good relations with their white neighbors, see Peter Hoehnle, "Die Colonisten und Die Indianer: The Unusual Relationship between the Meskwaki Nation and the Amana Society," Iowa Heritage Illustrated 92 (2011), 90-99.

16. L. Edward Purcell, “The Meskwaki Indian Settlement in 1905,” Palimpsest 55 (1974), 35.

17. For examples of times the tribe contacted Iowa governors for support during disagreements with the federal government, see the correspondence between Leander Clark and Governor Buren R. Sherman from July 1882, in Correspondence, Miscellaneous, Indian Affairs, 1860-1887, RG 43 Governor, State Historical Society of Iowa, Des Moines (hereafter SHSI-DM).

18. Buffalo, "1846-1856." On the permeability of tribal boundaries, see Jacki Thompson Rand, "Primary Sources: Indian Goods and the History of American Colonialism and the 19th-Century Reservation," in Clearing a Path: Theorizing the Past in Native American Studies, ed. Nancy Shoemaker (New York, 2002), 136-37. 
IN STARK CONTRAST to their relationship with the state, the Meskwaki were at odds with the federal government from the settlement's earliest days. The tribe's religion, economy, and political structure did not comport with the assimilatory agenda pursued by the OIA throughout the period. Federal administrators demanded that Native peoples across the country convert to Christianity, commit to a life of sedentary agriculture on individually owned plots of land, and embrace American-style democracy. The agency undertook strident efforts to force these changes upon Native Americans, including the Meskwaki, throughout the late nineteenth and early twentieth centuries. ${ }^{19}$

In an effort to force the Meskwaki back to Kansas, the agency convinced Congress to withdraw federal recognition from the tribe upon its exodus from the Indian Territory in 1856. As American Indian policy scholar Brian Klopotek explains, "Federal recognition establishes a political and legal relationship between a tribe and the United States that carries particular rights and responsibilities for both parties under federal law." 20 By revoking the tribe's recognition, then, the government could deny any responsibility to uphold the terms of earlier treaties, and refused to pay the Meskwaki the annuities that had contributed to the tribe's cash coffers for decades. OIA administrators assumed that without those funds, the tribe would be unable to survive and would return to Kansas, where it could be confined and controlled. ${ }^{21}$ Even without those funds, however, the Meskwaki continued to coexist peacefully with surrounding communities. Although tribal members may have been poor by white standards, the tribe as a whole did not suffer critically without its annuities; it subsisted, and during tough times some Meskwaki reached out to the state government or nearby settlers for support. ${ }^{22}$

19. See Frederick E. Hoxie, A Final Promise: The Campaign to Assimilate the Indians (Lincoln, NE, 2001).

20. Brian Klopotek, Recognition Odysseys: Indigeneity, Race, and Federal Tribal Recognition Policy in Three Louisiana Indian Communities (Durham, NC, 2001), 2-3.

21. Lewis V. Bogy to Leander Clark, 11/17/1866, quoted in Johnathan Buffalo, "1867-1886: The New Neighbors," Meskwaki History CD-ROM. See also Warren, "To Show the Public We Were Good Indians," 5; Brown, "Social History," 42-46.

22. See Green, "We Dance in Opposite Directions," 138; George L. Davenport to Samuel J. Kirkwood, 9/26/1862, Correspondence, Miscellaneous, Indian Affairs, 1860-1887, RG 43 Governor, SHSI-DM. 
After a decade, the OIA realized that its strategy had not broken the Meskwaki, and Congress restored the tribe's federally recognized status. The OIA paid annuities - some $\$ 5,588$ (nearly $\$ 90,000$ in 2013 dollars) - to the Meskwaki in the spring of 1867.23 From the government's perspective, this recognition provided a legal mechanism through which the United States could once again oversee the tribe as a "domestic dependent nation" and subject it to OIA authority - an effort that coincided with the federal government's reinvigorated interest in Indian affairs following the Civil War. Accordingly, the agency constructed an office near the settlement and assigned agent Leander Clark to the Meskwaki. His primary responsibility was to pay annuities to the tribe, but by "continually attempt[ing] to interest" tribal members "in settling permanently on farms," Clark and his successors also sought to carry out the OIA's broader agenda and to push tribal members toward assimilation. ${ }^{24}$

The OIA attempted religious conversion, education, and the management of tribal affairs in accordance with its overarching goals to "civilize" all Natives into "docile believers in American progress." 25 The OIA built a schoolhouse on the settlement and a pan-Indian school near the agency headquarters in nearby Toledo. Over the years, these facilities collaborated with churches on and near the settlement to expedite assimilation. ${ }^{26}$ Some years

23. Joffe, "Fox of Iowa," 289. According to Green, "We Dance in Opposite Directions," 138, although the federal government "did not explicitly recognize the Mesquakies, it did quite obviously recognize the existence of a distinct band of the 'Sacs and Foxes' who were separated physically from the rest of the 'united tribe.' " Indeed, the question of Meskwaki recognition as a distinct tribal entity remained unclear until 1901, when a court declared the tribe autonomous in Peters v. Malin. See Angela Keysor, "Emergence of a Distinct Legal Identity from the Forces of Assimilation: The Mesquakie Indians and the Fight for Citizenship, 1842-1912," Meskwaki History CD-ROM.

24. Brown, "Social History," 60. See also Hoxie, Final Promise, 2-3.

25. Hoxie, Final Promise, xvii.

26. Clark, "No. 85, Agency of Sac and Fox Indians in Iowa," in U.S. Office of Indian Affairs, Annual Report of the Commissioner of Indian Affairs, 1872 (Washington, DC, 1872), 515-16; Clark to Commissioner of Indian Affairs Eli S. Parker, 1871, quoted in Buffalo, "1867-1886: The New Neighbors"; Clark, "Sac and Foxes in Iowa No. 125, Agency of the Sac and Fox Indians Residing in the State of Iowa," in Message of the President of the United States and Accompanying Documents to the Two Houses of Congress at the Commencement of the Second Session of the Fortieth Congress (Washington, DC, 1867), 349. For further information on the 
later, the OIA even burned the settlement village with the dual purpose of tempering a smallpox outbreak and dispersing the Meskwaki onto individual sections scattered throughout tribal land. ${ }^{27}$ Still, the Meskwaki refused the agency's vision of individual land ownership, and the tribe continued to share the settlement, following a usufruct system: Families selected a section of the settlement to occupy, constructed their dwellings, and cultivated small subsistence gardens. Tribal members passed on their use of a particular portion of the settlement to their descendants. ${ }^{28}$

The government's decision to recognize the Meskwaki reflected, at least in part, an OIA strategy aimed at nudging the tribe away from subsistence and toward the local cash economy. From the Meskwaki perspective, however, it also created an opportunity for the tribe to exercise its sovereignty and tilt its precarious position between the state and federal governments to its advantage. Immediately upon receiving their payment in 1867, tribal members asked Clark to set aside $\$ 2,000$ of their annuities to purchase additional settlement lands. Clark agreed, and the tribe convinced him to facilitate its property purchases throughout his tenure. Despite the overarching assimilative agenda of the agency for which he worked-and its preference that the Meskwaki remain in Kansas-Clark was in some respects sympathetic to tribal concerns over handling their own affairs. He proved open to cooperating with the tribe, and tribal members even persuaded him to allow other Meskwaki to rejoin their growing community in Iowa. ${ }^{29}$

use of boarding schools to fuse religious conversion and non-Indian education to further the project of assimilation, see John Troutman, "The Citizenship of Dance: Politics of Music among the Lakota, 1900-1924," in Beyond Red Power: American Indian Politics and Activism Since 1900, ed. Daniel M. Cobb and Loretta Fowler (Santa Fe, NM, 2007), 91-108; and Clifford E. Trafzer, Jean A. Keller, and Lorene Sisquoc, eds., Boarding School Blues: Revisiting American Indian Educational Experiences (Lincoln, NE, 2006).

27. Warren, "To Show the Public We Were Good Indians," 2-3, explores how the 1901 village burning fit the OIA's assimilationist agenda.

28. Daubenmier, Meskwaki and Anthropologists, 34.

29. Joffe, "Fox of Iowa," 289; Leander Clark to E. S. Parker, “Second Quarter Report, 1867," 5/17/1867, file "Leander Clark-Correspondence 1866-69, 1872 Copies of Letters," box BL 57, State Historical Society of Iowa, Iowa City (hereafter SHSI-IC); Clark to E. B. Fenn, 2/24/1868, ibid. 


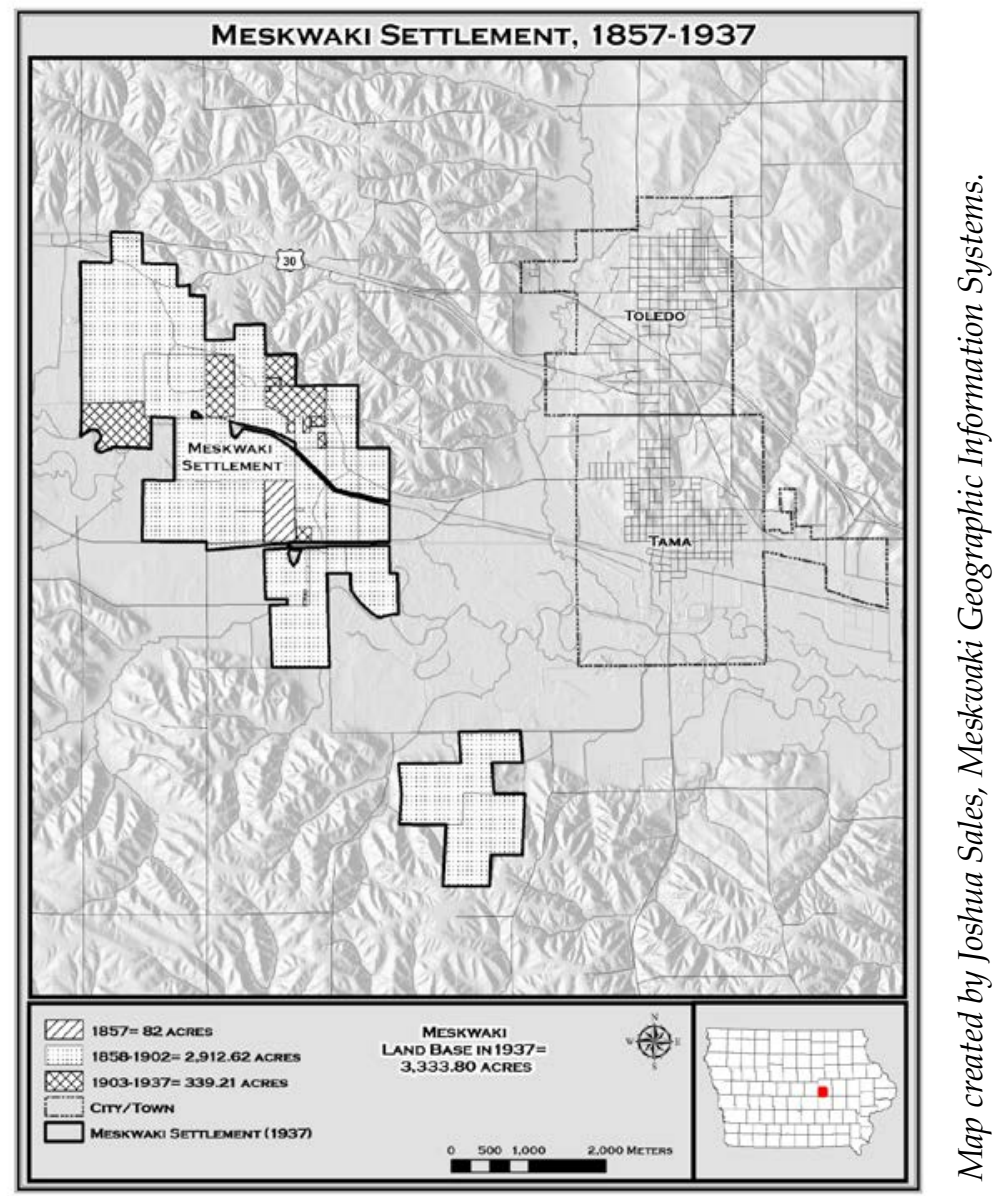

From 1867 forward, writes one historian, the Meskwaki had "an almost fanatic desire" to purchase land as opportunities arose, and the settlement grew to over 3,000 acres by 1915.30 Very few sources from this era provide Meskwaki perspectives, but it appears that they had a prescient and pragmatic understanding of their position vis-à-vis the state and federal governments. Although federal recognition provided an opportunity for the OIA to establish local offices and schools and to pressure the tribe to assimilate, it also secured valuable cash assets the Meskwaki could

30. Brown, "Social History," 59; Daubenmier, Meskwaki and Anthropologists, 33. 
use to purchase their land via their trust relationship with the state. In this way, tribal members negotiated their relationships with both governments and capitalized on the decentralized nature of the American federal system to protect and affirm Meskwaki sovereignty. Because "sovereignty takes material form and is built with material resources," as the anthropologist Jessica R. Cattelino argues, it is clear that by expanding its land base, the tribe could subsist, stabilize its population, create a physical buffer between itself and its neighbors, and prepare for future growth. ${ }^{31}$

Meskwaki political maneuvering also spared them from two of the most destructive epochs in the history of federal Indian policy. First, they were largely unaffected by the so-called Indian Wars between 1850 and 1890. Instead, they maintained generally peaceful relations with their white neighbors. ${ }^{32}$ Second, the tribe avoided the ravages brought on by the 1887 Dawes Act, which established the allotment policy that dispossessed Native peoples nationwide of some 80 million acres of land by 1934. ${ }^{33}$ The Meskwaki escaped that fate precisely because their ownership of the settlement helped insulate them from the unilateral authority Congress held over federally assigned reservations.

Over the next several decades, tribal members opposed even subtle OIA efforts to control their affairs. In 1876, for example, the federal government mandated that all tribal members had to register with the agency in order to receive annuities. Most Meskwaki grew suspicious of the government's motives and refused to register, leading the OIA to punitively withhold annuitiesjust as it had during the decade before they were re-recognized in 1866. Much was at stake. The tribe did not rely completely on the annuities for subsistence, but the purchase of additional land

31. Jessica R. Cattelino, High Stakes: Florida Seminole Gaming and Sovereignty (Durham, NC, 2008), 128.

32. A.R.F., "The Indians of Iowa," Daily Iowa State Register, 11/18/1869. On "Indian Wars and Skirmishes," see Walter R. Echo-Hawk, In the Courts of the Conqueror: The Ten Worst Indian Law Cases Ever Decided (Golden, CO, 2010), 137.

33. Stuart Banner, How the Indians Lost Their Land: Law and Power on the Frontier (Cambridge, MA, 2005), 256-92; Douglas E. Foley, "The Fox Project: A Reappraisal," Current Anthropology 40 (1999), 187. The Dawes Severalty Act of 1887, 49th Cong., 2nd sess. (2/8/1887), 388, is also known as the General Allotment Act or simply the Dawes Act. 
depended in part on the funds. Led by the chief's council, the Meskwaki refused to sign the rolls. The ensuing stalemate lasted nearly six years, with the tribe capitulating only after the lack of revenue led them to default on their property taxes in 1878, and the Secretary of the Interior personally assured Meskwaki leaders that enrollment would not decrease their annuities. Technically, the default breached the trust agreement with the state, and the Tama County government claimed the settlement briefly, but in title only. In an expression of ongoing cooperation, Iowa extended the deadline for payment to late 1882 , which the tribe met. ${ }^{34}$

During this episode, the Meskwaki narrowly avoided an effort to dismantle the settlement and force them back to Kansas. In 1878 combined pressure from the OIA and angry petitions from some Iowans nearly spurred Iowa to terminate its trust relationship with the tribe and almost prompted the U.S. Congress to remove them once again. ${ }^{35}$ The OIA supported that effort, believing that returning the Meskwaki to the tightly controlled Indian Territory would speed their assimilation. But many locals supported the tribe and petitioned the Commissioner of Indian Affairs, expressing their belief "that it would be an act of great injustice ... and a breach of faith on our part, to remove [the tribe] without their consent, from their own lands which they have purchased." These neighbors viewed the Meskwaki as "peaceable, quiet, honest and law abiding people [who] compare[d] favorably in their obedience to the laws with the . . . whites surrounding them." Iowa legislators sympathized with that view and did not alter their relationship with the Meskwaki. Assimilationists, however, still held sway in Washington, D.C. In early 1878 a resolution for the tribe's removal made it through the House of Representatives. Fortunately for the Meskwaki, who were "unanimously and utterly adverse" to the prospect of returning to Kansas, the resolution failed to pass the Senate, and the issue was not reconsidered. ${ }^{36}$

34. Brown, "Social History," 61-63.

35. "To the Hon. Geo. W. McCrary, Secretary of War," 5/14/1878; and "To the Hon. Commission of Indian Affairs, Washington, D.C.," both quoted in Buffalo, "1867-1886: The New Neighbors."

36. "To the Hon. Commission of Indian Affairs, Washington, D.C.," quoted in Buffalo, "1867-1886: The New Neighbors"; A. R. Howbert, 1873, ibid.; T. A. Graham to John R. Rankin, 4/30/1878, ibid. 
DESPITE the relative strength of their tribal sovereignty and their ability to elude these various attacks on their residency in Iowa, the Meskwaki did not completely avoid the corrosive effects of shifting federal Indian policy at the end of the nineteenth century. As thousands of American Indians died in confrontations with the U.S. military and from starvation on ill-supplied reservations, the Meskwaki continued to subsist in relative obscurity through the 1880s. Yet they remained vulnerable to increasing pressures to intervene in their affairs. Such threats would abruptly and fundamentally alter the Meskwaki ability to exercise their sovereignty by century's end. In 1888, for example, and despite the tribe's previous aversion to the practice, the OIA completed its first official Meskwaki census, listing 381 tribal members on government rolls. ${ }^{37}$

An even more substantive change took place in 1891, when the OIA accelerated its efforts to reform tribal governments nationwide. That February, Congress authorized the creation of "tribal business councils" that "could make decisions on behalf of the tribe in transactions involving tribal or nonallotted lands." That initiative undermined tribes' chosen systems of governance by imposing a managerial formation with democratic overtones. Business councils would replace any existing form of tribal governance-for the Meskwaki, the chief-council system-and require that council members be elected by majority vote, thereby decreasing the power of clans, the chief, and decision making by consensus. In keeping with the American exclusion of women from the vote-and contrary to Meskwaki practice-only men would be allowed to participate in OIA business council elections. Because the settlement was technically "non-allotted land," the Meskwaki could have organized a business council, but they refused, deeply frustrating the OIA. One agent complained that Meskwaki obstinacy was "the worst problem to deal with ... among any of the Indians" in the country. He advocated "break[ing]" tribal leaders" "power and influence" to strengthen OIA control. ${ }^{38}$

37. Enos Gheen to John D. C. Atkins, 7/20/1888, microcopy 595, roll 450, Indian Census Rolls, 1885-1940, Sac and Fox, IA, 1888-1910, National Archives Microfilm Publications (Washington, DC, 1965).

38. Loretta Fowler, Arapahoe Politics, 1851-1978: Symbols in Crises of Authority (Lincoln, NE, 1982), 98; Buffalo, "Historical Overview," 4; Horace M. Rebok, 
To do so, the trust relationship between the tribe and the state also had to be broken. This issue erupted in 1895. Some local whites organized a branch of the Indian Rights Association, a national group of assimilationist Christian reformers who believed in the destruction of Indian religions, languages, governance, and communal land ownership. ${ }^{39}$ The group lobbied to transfer the settlement from Iowa to the United States, a strategy many state legislators also increasingly supported-even if only as a way to quiet this surge in local unrest. Illustrating this dramatic turn in the state's Indian policy, Iowa Governor Francis M. Drake advocated assimilation for the Meskwaki, apologetically telling them that adopting American culture was "the better way to live." 40

On June 10, 1896, the political tide of American colonialism, which the Meskwaki had skirted for so long, swept in. Bowing to pressure from assimilationists, the state transferred jurisdiction and the land trust to the federal government, giving it the same legal status as other tribal lands. Congress accepted the transfer the same day, officially making the federal government the sole trustee over the Meskwaki settlement. Yet questions over the status of Meskwaki land, taxation, and criminal jurisdiction would continue well into the twentieth century. ${ }^{41}$

Despite these ambiguities, and the fact that the tribe owned and controlled its land, the 1896 transfer put the Meskwaki in a position shared by almost every other American Indian tribe: in an unequal trust with, and thus highly subordinate to, an overzealous OIA. Native scholar Walter Echo-Hawk has argued that the OIA's " powers over Indian tribes reached their zenith" at that

\footnotetext{
"Report of Agent in Iowa, Report of Sac and Fox Agency," in U.S. Office of Indian Affairs, Report of the Commissioner of Indian Affairs to the Secretary of the Interior, 1895 (Washington, DC, 1896), 165-69.

39. Benay Blend, "The Indian Rights Association, the Allotment Policy, and the Five Civilized Tribes, 1923-1936," American Indian Quarterly 7 (1983), 67.

40. "Indians Claim Damages," Annals of Iowa 3 (1897), 130-34.

41. Sacs and Foxes of the Mississippi [Jurisdictional Transfer], 54th Cong., 1st sess., 6/10/1896, 598. Brown, "Social History," 65, notes that "the State of Iowa . . retained control over any judicial process within the settlement, jurisdiction of crimes against the laws of Iowa committed within the settlement by Indians or others, and the privilege of establishing and maintaining highways ... [as well as] eminent domain over Indian lands for state and county purposes." On the application of Iowa law to the Meskwaki, see also Joffe, "Fox of Iowa," 311-12; and Daubenmier, Meskwaki and Anthropologists, 48-57.
} 
time. For about 50 years, beginning in 1886, the agency took Indian land across the country, increased its paternalistic control over tribal affairs, and cleared the way for the total "assimilation of Indians into settler society." 42 Although the tribe still owned its settlement and would continue to pay state taxes for decades, and although legal questions over the first land purchase in 1857 delayed the transfer, the federal government finally took all of the settlement lands into trust in 1908.43 As Meskwaki author and elder Donald Wanatee writes, his tribe suddenly found itself "governed under a separate law, administered by members of the White community" and increasingly "in a position of definite subordination" to the OIA. ${ }^{44}$ The tribe would struggle to maintain its sovereignty in coming years, but its ability to negotiate with the federal government and manage its affairs was nearly broken during the first several decades of the twentieth century.

THE 1896 TRUST TRANSFER had opened the Meskwaki to external influence, but a key part of the ensuing political transformation was rooted in an intratribal controversy that had begun 15 years earlier. The dispute soon created a deep political schism that-with much encouragement from the OIAdamaged the tribe's ability to assert self-governance as the nineteenth century came to a close. At the height of the enrollment stalemate in 1881 an influential chief named Mamiwanige died. He had presided over the tribe since it established the settlement. Upon Mamiwanige's death, his eldest son succeeded to his leadership position, per tribal custom. That son, however, also died just a few weeks later. Faced with a leadership vacuum, the chief's council acted quickly to install a new leader named Pushetonequa. ${ }^{45}$

That decision had long-lasting effects on tribal politics. Most Meskwaki initially accepted the council's decision to recognize Pushetonequa as chief. But the seeds of discord had been sown:

42. Echo-Hawk, Courts of the Conqueror, 189-91.

43. Daubenmier, Meskwaki and Anthropologists, 33.

44. Donald Wanatee, "The Lion, Fleur-de-lis, the Eagle, or the Fox: A Study of Government," in Worlds Between Two Rivers, 79.

45. Buffalo, "Historical Overview," 3-5; Brown, "Social History," 62-63. 
In order to seat Pushetonequa, the council bypassed two of Mamiwanige's younger sons, who were considered "too young and incompetent" for the chieftainship. Thus, a dispute over tribal custom and hereditary right began to ferment. In the meantime, Pushetonequa led the tribe toward the twentieth century with his people's general support. ${ }^{46}$

In the late 1890s, many local whites still supported the Indian Rights Association and the OIA; they fervently believed in assimilation and noted their frustration with the tribe's success in repelling any such efforts. The 1896 trust transfer had been a major victory for the reformers, who quickly set about further efforts to undermine tribal sovereignty and "civilize" the Meskwaki. ${ }^{47}$ The transfer itself had provided the U.S. the authority to purchase land in Tama County for federal schools to manage Meskwaki education. ${ }^{8}$ Observing the agency's continued inability to assimilate tribal members, Congress authorized the construction of a pan-Indian boarding school next to the Indian Office in Toledo. 49

When the OIA ordered the Meskwaki to enroll their children at the new school, tribal families unanimously refused. In November 1898 Pushetonequa and several councilmen traveled to the nation's capital, where the OIA attempted to bribe Pushetonequa with an official designation as the "Head [Meskwaki] Chief" and a \$500 annual salary. He declined. The government next threatened to send children from other tribes to the settlement school. That, the OIA said, would lead to eventual intermarriage with other tribes - a practice many Meskwaki opposed for fear of diluting their annuities across a larger population. Pushetonequa acquiesced, and he and several council members enrolled their children in mid-December. Their decision was unpopular, and most Meskwaki opposed the boarding school for

46. Wanatee, "Study of Government," 79; Buffalo, "Historical Overview," 3.

47. Horace M. Rebok, History of the Indian Rights Association of Iowa and the Founding of the Indian Training School (Toledo, IA, 1897); H. Sutherland, "That Indian Scare," Midland Monthly 8 (1897), 519.

48. "An Act Tendering to the United States Jurisdiction over Certain Indians Residing in Iowa and over Their Lands, and the Privilege of Purchasing Land in Tama County for Indian School Purposes" (2/14/1896), Acts and Resolutions Passed at the Regular Session of the 26th General Assembly of the State of Iowa, ch. 110 (1896), 114-15.

49. Daubenmier, Meskwaki and Anthropologists, 35; Brown, "Social History," 69-70. 
another decade. Low enrollment forced its eventual conversion into a sanatorium for tuberculosis patients in 1911.50

Pushetonequa's concession to the OIA deepened the growing dispute over his leadership. As early as 1898, one of Mamiwanige's bypassed sons, Oldbear, began disparaging Pushetonequa as a corrupt "government chief." Oldbear and his supporters framed Pushetonequa's acquiescence as greedy and against tribal interests, using it as a polemical issue to bolster Oldbear's claim to hereditary leadership. ${ }^{51}$ Anthropologist Douglas Foley suggests a lack of any evidence supporting Oldbear's claim that clan requirements or hierarchies could preclude anyone, including Pushetonequa, from tribal leadership positions. Thus the entire chieftainship dispute may have "hinge[d] on how strict" tribal succession rules were. ${ }^{52}$

Nevertheless, the disagreement perpetuated an "ongoing fracture" in the community and eventually morphed into an ideological battle that changed Meskwaki politics. ${ }^{53}$ This new politics only worsened after the OIA recognized Pushetonequa as the head chief in 1900-the same title it had offered in 1898. The chief's detractors quickly derided him "as a pawn in the white man's assimilation policy," and rumors about his true allegiance quickly spread across the settlement. The controversy slowly overtook tribal politics, and tribal members, local whites, and OIA agents began to measure political turmoil on the settlement by constructing a crude cultural binary that divided the tribe. In their paradigm, "Youngbears" supported Pushetonequa and were seen as "progressive" supporters of acculturation. The "Oldbears," on the other hand, were considered "anti-white" and "culturally conservative." 54

50. Brown, "Social History,” 69-70; Lisa Dianne Lykins, “'Curing the Indian’: Therapeutic Care and Acculturation at the Sac and Fox Tuberculosis Sanatorium, 1912-1942" (Ph.D. diss., University of Kentucky, 2002).

51. Buffalo, "Historical Overview," 5; Brown, "Social History," 68.

52. Douglas E. Foley, The Heartland Chronicles (Philadelphia, 1995), 153-55.

53. Warren, "To Show the Public We Were Good Indians," 8.

54. Buffalo, "Historical Overview," 5; Foley, Heartland Chronicles, 153-54; Lisa Peattie, "Being a Mesquakie Indian," in Documentary History of the Fox Project, 1928-1959: A Program in Action Anthropology Directed by Sol Tax, ed. Fred Gearing, Robert McC. Netting, and Lisa R. Peattie (Chicago, 1960), 48. 
Scholars have overemphasized this factional split as the central organizing theme of modern Meskwaki politics, in part because they have failed to adequately recognize OIA efforts to perpetuate and enflame political tensions in order to divide and control the tribe. But, as Judith $\mathrm{M}$. Daubenmier writes, the Oldbear/Youngbear binary is "vague [and] simplistic" and does not accurately depict the ongoing Meskwaki conversations over tribal governance. ${ }^{55}$ Meskwaki disagreement over Pushetonequa's leadership certainly existed, and those vying for power often flung rhetoric framing the battle as one between progressives and conservatives. But tribal politics were never clearly dichotomous, and many tribal members did not identify with either faction. Rather, tribal leaders and their constituents alike attempted to determine the best course for their people during a chaotic and, at times, politically acerbic period, and to make their voices heard. ${ }^{56}$

Shedding light on the ways Meskwaki political discord played into the government's hands does not absolve some intransigent tribal members of their role in exacerbating a difficult political situation, but it does reveal the ways OIA agents exploited a tense political situation to further their assimilatory goals. The OIA recognized the opportunity created by the Meskwaki leadership dispute and endeavored to weaken the tribe's ability to resist agency initiatives. Horace M. Rebok, the tribe's agent

55. Daubenmier, Meskwaki and Anthropologists, 37. Such "factional binaries" have long been used to describe political discord within Indian tribes and have varied across Native contexts. For more on the perceived intersections of genetics and cultural awareness, see, for example, Lambert, Choctaw Nation, 37; Scott Richard Lyons, X-Marks: Native Signatures of Assent (Minneapolis, 2010); and Larry Nesper, The Walleye War: The Struggle for Ojibwe Spearfishing and Treaty Rights (Lincoln, NE, 2002), 185-97.

56. Other examples of the tendency to view Native leaders as ensnared in a rigid and intractable politics are challenged in Jeffrey Ostler, The Plains Sioux and U.S. Colonialism from Lewis and Clark to Wounded Knee (New York, 2004), 7; and Benjamin R. Kratch, "Kiowa Religion: An Ethnohistorical Analysis of Ritual Symbolism, 1832-1987" (Ph.D. diss., Southern Methodist University, 1989), 618. Ostler argues that "it is more productive to realize that Sioux leaders adopted a range of strategies based on reasoned assessments of changing conditions and possibilities." They "were not always locked into polar antagonisms" but instead "adjusted their tactics in light of new circumstances and were responsive to changing opinion[s] among their people," and all tried to do the "tough political work of mending fences and building unity." All of this was aimed toward shared goals: the survival of their people and the defense of their sovereignty. 
until 1899 and founder of the Iowa branch of the Indian Rights Association, remained committed, as he had so bluntly exclaimed three years earlier, to breaking the tribal leaders' power. He and his successors continued to wedge the tribe against itself. As a result of this continual prodding, by roughly 1905, Meskwaki political divisions had grown so entrenched that two separate tribal councils existed. One was sanctioned by the OIA and led by Pushetonequa and his supporters; the other was led by the Oldbears. Both sides vied for support from tribal members, while OIA agents fueled the already aggressive discourse, calculating that "the tribe was easier to control when divided" against itself. ${ }^{57}$

Given the various challenges facing the tribe throughout this period it is not surprising that the agency successfully provoked the Meskwaki devolution into a pronounced and vitriolic politics. In addition to the settlement trust transfer in 1896, deep changes that accompanied the turn of the twentieth century proved equally daunting. During the first three decades of the new century, residents of the Meskwaki settlement underwent substantial social and economic changes. The settlement's population had doubled since the 1850s. More than 90 Meskwaki children attended OIA schools in neighboring states for part of the year, while a few Meskwaki lived and worked in urban areas like Des Moines. ${ }^{58}$ In 1905 only about 15 framed houses had stood on the settlement; the majority of homes were still wickiups, the domed dwellings tribal members had customarily used. But by 1927 most Meskwaki lived in small "American-style" homes; only three families lived full-time in wickiups. ${ }^{59}$ The Meskwaki, like other tribes,

\section{Foley, Heartland Chronicles, 153-55.}

58. Ira D. Nelson, "1936 Annual Statistical Report," 1-8, in file Annual Reports 051, 1935-1943, box 114, Bureau of Indian Affairs, Sac \& Fox Agency, RG 75, National Archives and Records Administration, Great Lakes, Chicago (hereafter cited as NARAGL); George Young Bear, "Mesquakie News Tells of History: George Young Bear Gives Facts about Indian Education," Toledo Chronicle, $11 / 22 / 1928$. For a Meskwaki account of the assimilation project and the boarding school system, see Adeline Wanatee, "Education, the Family, and the Schools," in Worlds Between Two Rivers, 100-103.

59. Duren H. Ward Collection, BL21, folder 11, SHSI-IC; John J. Sullivan, "Sac and Fox Agency and Sanatorium, Iowa," 9, Report to the Commissioner of Indian Affairs, Samuel A. Elliot Collection, \#9165 Series I, Board of Indian Commissioners Reports, box 5C, Division of Rare and Manuscript Collections, Cornell University Library, Ithaca, NY; C. M. Richards, “Tama Indians Abandon Wickiups 
increasingly struggled to subsist via local hunting and farming. ${ }^{60}$ The tribe leased settlement land to local farmers to pay property taxes. Individuals continued to farm small plots of land and hunt near their homes, while many men also began laboring for railroads, factories, and farms. Several owned tractors and other tools, and more than 40 owned horses. ${ }^{61}$ English grew prevalent, though most continued to speak fluent Meskwaki. ${ }^{62}$ Tribal members explored faiths ranging from their customary clan/bundle ceremonies to the Native American Church and various Christian sects. ${ }^{63}$ They also "converted . . . culture into a commodity" by developing a powwow festival in 1913, performing for thousands of white tourists. ${ }^{64}$ Women made souvenir jewelry and toys for sale to tourists. ${ }^{65}$ One entrepreneurial Meskwaki even took to "raising silver foxes," presumably for sale locally. ${ }^{66}$ By forcing tribal members to carefully consider the best strategies for tribal economic, social, and political survival, these changes shaped Meskwaki politics as the tribe struggled to maintain its sovereignty in the early twentieth century.

Under these circumstances, the OIA incrementally increased control over Meskwaki governance. Although Oldbears continued

for Modern Homes; Progress in Last Few Years Was Greatest in History," Toledo Chronicle, 12/15/1927.

60. Warren, "To Show the Public We Were Good Indians," 21.

61. Joffe, "Fox of Iowa," 302-3.

62. Ibid., 294; "1936 Annual Statistical Report," 1, file Annual Reports 051, 19351943, box 114, NARAGL; "100 Persons from Our County Hear Story of Indian," Newton News, 4/18/1935.

63. Peattie, "Being a Mesquakie Indian," 44-46; "Percy Bear," Surveys of Indian Industry, 1921-1926, box 1, NARAGL; "1936 Annual Statistical Report," 1-11, file "Annual Reports 051, 1935-1943," box 114, NARAGL; Donald Grant, "The Indian-Union of Primitive, Modern Culture: Radios, Newspapers, Cookstoves, Modern Homes Fail to Crowd Out Age-Old Customs at Tama Reservation," Des Moines Register, 6/17/1934. See also Buffalo, "The Meskwaki World amid Centuries of Spiritual Assault: Historical Perspective on Alien Belief Systems Imposed on the Meskwaki Tribe," unpublished manuscript, folder "Buffalo, Johnathan L., The Meskwaki World amid Centuries of Spiritual Assault 2012," SHSI-IC.

64. Warren, "To Show the Public We Were Good Indians," 21; Sol Tax, "The Social Organization of the Fox Indians" (Ph.D. diss., University of Chicago, 1935), in Gearing et al., Documentary History, 5-6.

65. Nelson, “Annual Report, January 1, 1935," file “Annual Reports 051, 19311935," box 113, NARAGL; Tax, "Social Organization," 5.

66. Grant, "The Indian." 
to criticize Pushetonequa, his cooperation with the OIA actually remained limited. Whites viewed him as a hindrance to assimilation, and even famed anthropologist George Bird Grinnell opined that the chief's frequent opposition held the tribe back. ${ }^{67}$ Yet discord prevailed. In early 1914 some 200 tribal members petitioned that Pushetonequa be replaced with Peter Old Bear, one of his primary political rivals. Although their demand was not met, OIA Superintendent Robert L. Russell seized the opportunity to increase federal control. Lamenting the Oldbear/Youngbear dispute as irreconcilable, he characterized the tribe as dysfunctional and its politics as detrimental to assimilation. That March, Russell asked the OIA for the authority to appoint the Meskwaki chief's council - a responsibility usually left to the chief. The tribe attempted to maintain control of the council and offered to reduce it from 12 members to 5, whom they would elect directly. Meanwhile, several Oldbears again petitioned the OIA to repeal Pushetonequa's title. Recognizing the importance of maintaining a veneer of tribal authority, the OIA decided to temporarily leave the chief in his position and the council at 12 members. This apparent equilibrium did not last long. By October 1914, the OIA superintendent was unilaterally selecting council members, enabling the agency to drastically reduce Pushetonequa's authority. The effects of these intrusive OIA strategies were staggering. Indeed, tribal historian Johnathan Buffalo argues that after the loss of power to select council members, Pushetonequa's "potency to act" as a tribal leader "was broken." 68

From that point until 1929, Meskwaki governance took the form of an agency-appointed business council. That was a far cry from self-governance as it had existed before 1896 and was also eerily similar to the tribal business councils the OIA had unsuccessfully attempted to form in the 1890s. Nearly subsumed by OIA pressure, the council struggled to maintain any semblance of the authority it previously wielded. The OIA incrementally tightened its grip on local authority by reducing the council from 12 members to 5 and refused to recognize a new chief following Pushetonequa's death in 1919. Without clear leadership and still

67. George Bird Grinnell, The Indians of To-day (New York, 1915), 283.

68. Buffalo, "Historical Overview," 7-8. 
grappling with partisanship, the council "refused to meet for a year" until the OIA replaced it. The new group also held "little or no authority" and functioned only to "validate agency decisions, to communicate these decisions [to the tribe], and to report tribal community reactions" to agency decrees. ${ }^{69}$

Although the Meskwaki stood at a disadvantage to the OIA after 1919, tribal members remained politically active and never abandoned their quest for local control. The Indian Citizenship Act of 1924 conferred federal citizenship on all Native Americans in the United States; thereafter, many Meskwaki vociferously exercised their newfound vote in non-tribal elections. Even as the OIA managed tribal "schools ... police, and most of their domestic affairs," as one Iowan wrote, many Meskwaki took great interest in education and government. Seventy-seven Meskwaki voted in the 1924 election, their first as U.S. citizens. ${ }^{70}$

In 1928 several Meskwaki-possibly exploring strategies for reaffirming their control over local activities - sent a letter to Commissioner of Indian Affairs Charles H. Burke about removing the tribe from federal trusteeship. In order to do so, he responded, the tribe would have to agree to fully allot the settlement into individually owned parcels. They did not. ${ }^{71}$

That same year the tribe launched a series of efforts to reclaim its governance. It held several meetings over the course of a month and nominated an Oldbear as chief who then selected a council. The tribe sought OIA recognition of this new government's authority, but the agency dodged the effort by insisting that the council be democratically elected. In May 1929 tribal members elected a seven-member council split between Oldbears and Youngbears. This attempt at bipartisanship, a reporter wrote, came with "great expectations" for a new era of political cooperation. The two groups, however, could not agree on several issues and, at various times, refused to meet. The tribe called several additional elections, each time hoping to seat a functioning

69. Ibid., 7-9; Daubenmier, Meskwaki and Anthropologists, 39.

70. Indian Citizenship Act of 1924, 68th Cong., 1st sess. (6/2/1924); Edgar R. Harlan to Mildred Hutchins, April 1936, file 49D, part 10, group 2, Edgar R. Harlan Papers, SHSI-DM; "Story of the Tama Indians," Boone News-Republican, 4/5/1928.

71. Buffalo, “Historical Overview," 10-11. 
council. Eventually, five elders organized an acting council, but even then one coalition dominated. 72

These post-1928 councils never achieved meaningful authority, although efforts to replace the acting council with an elected one continued until 1934. The OIA, however, stifled Meskwaki efforts at self-governance by consistently refusing to recognize any council "without a written constitution and without full tribal consent." 73 Even the acting council recognized its limitations; when an OIA agent asked it to settle a domestic relations dispute between two tribal members, the councilors stated that they "did not consider their authority sufficient to act as arbitrators ... or even to make a recommendation." 74

The Great Depression added economic strife to political turmoil. Before it began, Richard Brown writes, the Meskwaki were "poor" but "experienced no actual destitution." 75 The tribe's subsistence practices and recent efforts at economic diversification kept them afloat. But tribal members suffered more than most of their white neighbors because, as OIA Superintendent Jacob Breid remarked in early 1934, they did not have "a fair chance to get a job" until employment in white communities stabilized. ${ }^{76}$ Charities as far away as Des Moines and programs like the Civilian Conservation Corps-Indian Division and the Indian Relief and Rehabilitation Program provided much-needed relief. ${ }^{77}$ Meskwaki men and women found jobs in these programs or at the OIA sanatorium in Toledo, but the demand for employment

72. Ibid.; Toledo Chronicle, 5/9/1929; Nelson to John Collier, 2/23/1935, file "Letters Sent 1934," box 36, NARAGL.

73. Buffalo, "Historical Overview," 12.

74. Westwood, "Memorandum for Mr. Collier," IRA-MHPDM.

75. Brown, "Social History," 74.

76. Jacob Breid, "1934 Annual Statistical Report," 3, file “Annual Reports 051, 1931-1935," box 113, NARAGL.

77. Harlan to H. D. Bernbrock, 4/30/1932, file 49C, part 8; and H. M. Rhode, memorandum 12/15/1930, file 49C, part 7, both in Harlan Papers, SHSI-DM. For general information on the CCC-ID, see Donald L. Parman, "The Indian and the Civilian Conservation Corps," Pacific Historical Review 40 (1971), 39-56. For more on the IRRP and other Indian-oriented relief programs, see Virginia Davis, "A Discovery of Sorts: Reexamining the Origins of the Federal Indian Housing Obligation," Harvard Blackletter Law Journal 18 (2002), 211-39. 
stayed so high that officials had to rotate work schedules in order to spread wages as evenly as possible across the tribe. ${ }^{78}$

The 1920s and '30s were turbulent years on the Meskwaki settlement. Partisanship within the tribe was exacerbated by OIA efforts to divide the tribe against itself. The agency also successfully repelled repeated tribal efforts to reclaim the sovereignty it had wielded before 1896. With the nation reeling from the Great Depression, the Meskwaki would undertake an arduous initiative to regain control over their collective governance - an effort that reshaped tribal politics.

THE “INDIAN NEW DEAL" laid out the new approach to Indian policy taken by the administration of Franklin Delano Roosevelt. It included a variety of provisions to improve conditions for American Indians nationwide, spearheaded by FDR's Commissioner of Indian Affairs, John Collier. ${ }^{79} \mathrm{He}$ abandoned allotment and instilled new respect for tribal customs, replacing old policies with the Indian Reorganization Act. This sweeping law sought to remedy the numerous Indian policy failures identified in the sharply critical 1928 Meriam Report. ${ }^{80}$ Despite the improvements espoused by the Indian New Deal, continuities with earlier policies existed, as Cathleen D. Cahill points out, "particularly the [OIA's] tendency toward paternalism and essentialist thinking about Indigenous cultures." 81 But Collier's efforts became,

78. See boxes "CCC-ID Program Records," and "Indian Relief and Rehabilitation General Records," both in NARAGL. These collections offer general insight into the various relief projects taking place on the settlement in the 1930s. See also Lykins, "Curing the Indian," 147.

79. Kenneth R. Philp, John Collier's Crusade for Indian Reform, 1920-1954 (Tucson, AZ, 1977), 113-34. See also Harry A. Kersey Jr., The Florida Seminoles and the New Deal, 1933-1942 (Boca Raton, FL, 1989).

80. The "Meriam Report," written by the Brookings Institution, Institute for Government Research, is formally known as The Problem of Indian Administration: Report of a Survey Made at the Request of Honorable Hubert Work, Secretary of the Interior, and Submitted to Him, February 21, 1928 (Baltimore, 1928), and can be viewed at www.eric.ed.gov/PDFS/ED087573.pdf, accessed 5/30/2012.

81. Cathleen D. Cahill, Federal Fathers and Mothers: A Social History of the United States Indian Service, 1869-1933 (Chapel Hill, NC, 2011), 257. For more on Collier and the IRA, see Philp, John Collier's Crusade; Vine Deloria Jr. and Clifford M. Lytle, The Nations Within: The Past and Future of American Indian Sovereignty (New York, 1984); Akim Reinhardt, “A Crude Replacement: The Indian New 
at least for the Meskwaki, an opportunity to reestablish selfgovernance and defend their sovereignty.

Originally called the Wheeler-Howard Act, the IRA underwent an arduous period of legislative debate and amendment beginning in February 1934. As Congress considered the bill, Collier and his aides held a series of ten meetings in Native communities across the nation, where they pitched the ideals of the IRA to various tribal delegations. ${ }^{82}$ Those congresses, as they were called, provided an opportunity for the OIA to take its newly reconstituted mission - to replace "administrative absolutism" with local, tribal self-governance-from the bureaucratic halls of Washington to the communities it influenced. Neither Native communities nor Congress received the Wheeler-Howard Act as well as Collier had hoped, and the effort nearly floundered. Nonetheless, the much-altered bill became law on June 18, 1934, despite the obstacles presented by a highly polarized Congress. It ultimately offered a watered-down form of self-governance embodied in tribal constitutions that tribes could compose and ratify. Collier continued to claim that, despite the many changes made by Congress, the IRA still provided an opportunity for Indians to regain much of the independence and authority they had lost during assimilation. But their self-governance would continue to be couched under federal authority. ${ }^{83}$

Native tribes that chose reorganization took a series of steps. They first had to vote to accept the IRA and then draft a tribal

Deal, Indirect Colonialism, and Pine Ridge Reservation," Journal of Colonialism and Colonial History 6 (2005), 1-56; Graham D. Taylor, The New Deal and American Indian Tribalism: The Administration of the Indian Reorganization Act, 1934-1945 (Lincoln, NE, 1980); Felix S. Cohen, On the Drafting of Tribal Constitutions, ed. David E. Wilkins (Norman, OK, 2007); Elmer R. Rusco, A Fateful Time: The Background and Legislative History of the Indian Reorganization Act (Reno, NV, 2000); Wilcomb E. Washburn, "A Fifty-Year Perspective on the Indian Reorganization Act," American Anthropologist 86 (1984), 279-89; Jennifer McLerran, A New Deal for Native Art: Indian Arts and Federal Policy, 1933-1943 (Tucson, AZ, 2009).

82. Deloria and Lytle, Nations Within, 80-153, provides an excellent discussion on the congressional debates over the Wheeler-Howard Act. For the meetings with Native communities, see Vine Deloria Jr., ed., The Indian Reorganization Act Congresses and Bills (Norman, OK, 2002).

83. Haas, Ten Years of Tribal Government, 1; Deloria, Indian Reorganization Act, xv; Collier, "Facts about the New Indian Reorganization Act: An Explanation and Interpretation of the Wheeler-Howard Bill as Modified, Amended, and Passed by Congress," 9-10, file 46U, part 43, group 4, Harlan Papers, SHSI-DM. 
constitution under OIA guidance. Such assistance included a process of repeated revision and a clear agency effort to pressure tribes to integrate democratic governance into their constitutions. The IRA required the Secretary of the Interior to call a ratification election once tribes had a completed draft and, assuming tribal approval, the secretary had to formally approve the document for it to take effect. ${ }^{84}$

For the Meskwaki, this process began in April 1934 even as Congress debated the Wheeler-Howard Act and Collier and his OIA held its congresses across the country. At a meeting on April 7, the tribe selected an eight-member committee to study, interpret, and explain the IRA. Over the course of nearly 20 such meetings, this group went over the law, carefully weighing and explaining its merits to tribal members. ${ }^{85}$ Edgar R. Harlan, curator of the Historical, Memorial, and Art Department of Iowa (now known as the State Historical Society) in Des Moines, sent an inquiry to Collier in September 1934 on behalf of several Meskwaki as to the full impact the legislation would have on the tribe. Harlan, a non-Native widely viewed by the Meskwaki as a friend and advocate, noted that many Meskwaki were unclear about the changes between the original Wheeler-Howard Bill and the final IRA. He therefore requested an explanation of precisely those sections that would directly affect the Meskwaki, given the settlement's unique status as both communally owned and in a federal/tribal trust. Harlan noted that such an explanation would clarify the IRA for the Meskwaki "so that each individual, regardless of his factional attitude, may know exactly what he is in favor of, and what the law proposes, and what he is against." Harlan further observed that most opposition stemmed from Meskwaki suspicions of IRA provisions that had nothing to do with their tribe; they tended to doubt new policies that appeared "manifestly intended for a different tribe or culture." 86

84. Deloria and Lytle, Nations Within, 141. Hass, Ten Years of Tribal Government, 3, notes that from 1934 to 1936, 181 tribes accepted the IRA while 77 rejected it.

85. Buffalo, "Historical Overview," 15-17.

86. Harlan to Collier, 9/25/1934, file 49U, part 43, group 4, Harlan Papers, SHSIDM. Harlan was a close friend of the tribe throughout his career as the curator at the precursor to the State Historical Society of Iowa. He worked directly with Jonas Poweshiek (a Meskwaki who lived in Des Moines and worked at the 
The tribe was well aware of the Indian Office's steadfast support for the IRA. The agency strongly encouraged the new policies and showed little restraint in selling them to the Meskwaki. Collier asserted that there would be no retribution against tribes that did not accept reorganization, but he presented them with a harsh alternative, arguing that tribes that refused the IRA would "merely drift to the rear of the great advance open to the Indian race." It is not implausible, therefore, that the Meskwaki felt threatened by Collier's rhetoric, especially as he argued that nonIRA tribes would "stand still and ... continue to lose [their] lands." 87

A complex political situation developed around the IRA issue, and lasted throughout the process. ${ }^{88}$ While many Meskwaki viewed reorganization as a new and effective tool for self-governance, others wanted to reject it and return to the chief-council system. ${ }^{89}$ Still others rejected both proposed options, refused to participate in the process, or were undecided on the issue.

When the IRA became law in 1934, the tribe had already been working toward the restoration of its self-governance for over half a decade. Yet the form of that self-governance and, more importantly, who would be at the helm, remained unclear. Some feared that reorganization would provide disproportionate political advantage to IRA supporters. For some tribal members, the old politics reemerged, complicating matters even further: the Youngbears, it was popularly assumed, supported the IRA, while many Oldbears opposed it. ${ }^{90}$ It is reasonable to assume that a third group also existed outside this rigid binary: tribal members who weighed their support for reorganization not because of any factional affiliation but because they were undecided as to

historical society), was ceremonially adopted into the tribe in the early 1920s, and frequently acted as a liaison between the tribe and non-Indians.

87. Collier, "Facts about the New IRA," 16.

88. Daubenmier, Meskwaki and Anthropologists, 40-46, offers an excellent account of the Meskwaki encounter with the IRA elections and the constitution-making process.

89. Edward Davenport, George Young Bear, Horace Poweshiek, and William Poweshiek to John Collier, 6/29/1937; Young Bear, Charles Davenport, C. H. Chuck, Peter Morgan, John Tataposh, and Sam Slick to John Collier, 12/13/1937, both in IRA-MHPDM.

90. Brown, "Social History," 80; Foley, Heartland Chronicles, 151. 
whether the law posed effective solutions to the political problems their people faced.

An election in June 1935 offered the Meskwaki only two choices: accept or reject reorganization. Several Meskwaki opposed the IRA based on their recollections of the pre-1896 era. Jack Old Bear and four others wrote to Secretary of the Interior Harold Ickes in December 1934, arguing that, as owners of their land, the Meskwaki should not have to comply with the IRA. Instead, they argued, the tribe was "capable of self-government" without the law and was already attempting to seat a governing council. Fearing that reorganization would strip them of ownership of the settlement, they asked to be exempted from the law. ${ }^{91}$ Collier responded on Ickes's behalf, assuming that the Meskwaki had misunderstood the act. He reassured them that the IRA would not disrupt their collective ownership and reaffirmed their right to hold an IRA election. ${ }^{92}$

Collier's response did not satisfy the many tribal members who remained unsure of the effects the law would have on their community. As opposition grew, Collier asked the agency superintendent, Ira D. Nelson, to gauge Meskwaki inclinations toward the bill and to uncover the causes of Meskwaki discontent. Nelson responded, noting that, based on his observations at a tribal meeting, only a few Meskwaki opposed the law. By May 1935, the Meskwaki had organized a number of meetings at which the IRA's provisions were explained and discussed in detail, and Nelson reported that he had made every effort to thoroughly explain them. He admitted, however, to feeling that certain tribal members would be "much better satisfied" by a visit from another OIA official prior to the election. The agency accordingly sent two representatives to Tama to discuss the IRA just before the election. They were likely tasked with promoting the law to tribal members. 93

Their efforts paid off. During the election of June 15, 38 percent of eligible Meskwaki turned out to vote. They accepted the

91. Jack Old Bear, Joe Peters, Harrison Kapayou, and John Tataposh to Ickes, 12/18/1934, IRA-MHPDM.

92. Collier to Old Bear, 1/21/1935, IRA-MHPDM.

93. Ibid.; Nelson to Collier, 5/18/1935, IRA-MHPDM; Collier to Nelson, 5/24/ 1935 and 6/11/1935, IRA-MHPDM. 
IRA by a wide margin of 63 to $13 . .^{94}$ The election was notable for two main reasons. First, and most obviously, the Meskwaki accepted the law, moving their tribe into the second phase of reorganization. Second, although the wide margin of victory seemed to show overwhelming support for the IRA, the reality was far more complicated: The amount of Meskwaki "opposition was much greater than the number of 'no' votes would indicate," because some 62 percent of tribal members, who were either undecided on the issue or opposed reorganization outright, intentionally abstained from voting. ${ }^{95}$

The opposition had attempted to nullify the IRA election through boycott. Convention incorrectly holds that the abstainers did not understand democratic elections or thought they were following tribal custom and believed that by not showing up, they would be counted as voting against the IRA. Also, it has been argued, the low voter turnout may have been due to an inability of many tribal members to travel to the ballot place. Both of these arguments fail to recognize that many Meskwaki had been participating in democratic elections for over a decade and that agency reports describe the settlement as "small and [therefore] easy for the voters to get together," especially in the good weather offered by a June election. ${ }^{96}$ Thus, some tribal members may have opposed the IRA due to their political affiliations, others because they suspected that the IRA would negatively affect their community or land ownership. Still others could have had any number of reasons not to support the law. But none of these rationales should be equated with a widespread misunderstanding of an electoral process in which tribal members had been participating for years.

A more likely explanation lies in the possibility that the opposition misinterpreted Section 17 of the IRA, leading them to develop a strategy that would use a loophole to stymie the legislation. Nelson noted in a spring 1936 letter to Collier that those opposing the IRA "claim[ed] that it is necessary for at least thirty percent

94. Nelson to Collier, 6/15/1935, IRA-MHPDM.

95. Daubenmier, Meskwaki and Anthropologists, 43. See also Buffalo, "Historical Overview," 17-18.

96. Benjamin Reifel to Collier, 3/5/1937, IRA-MHPDM. 
of the adult Indians of the reservation to sign a petition requesting and authorizing the adoption of the proposed constitution and bylaws." 97 Although this letter came several months after the 1935 election, it suggests that some anti-IRA Meskwaki thought that by abstaining from the election the previous June, they could keep the electoral turnout below 30 percent. Doing so, they mistakenly believed, would nullify the IRA. Their interpretation of the law was inaccurate because, although the 30 percent provision did exist, it only applied to tribal corporate charters, not to elections for the IRA or for constitutional ratification. ${ }^{98}$ The abstentions, then, reveal another calculated - if ultimately unsuccessful - effort by some Meskwaki to prevent reorganization and maintain their customary system of governance.

The OIA and Meskwaki supporters of reorganization disregarded their opponents as legally naïve and quickly set about drafting the Meskwaki constitution following their 1935 victory. Several eager Meskwaki had elected a constitutional committee in 1934, before the IRA had even become law. That group, which included George Young Bear, Edward Davenport, and brothers Horace and William Poweshiek, worked in close conjunction with the agency for some 18 months to craft the document. They requested and amassed copies of constitutions from other tribes and used them as guides while OIA agents critiqued the document's form and language. The OIA did leave the majority of the legal decision making to the tribe. The committee proceeded very slowly through each stage of the process, wary of making mistakes or drafting language the tribe might not accept. OIA field agent Benjamin Reifel, observing this caution, called the committee "one of the most exacting that I have ever worked with." Another administrator called them "extraordinarily painstaking in their deliberations." 99

97. Nelson to Collier, 3/19/1936, IRA-MHPDM.

98. F. H. Daiker to Nelson, 5/18/1936, IRA-MHPDM. See also Indian Reorganization Act, sec. 17.

99. Daubenmier, Meskwaki and Anthropologists, 40-41; Cedar Rapids Gazette, 5/17/ 1936; Westwood, "Memorandum for Mr. Collier"; Reifel to Ed Davenport, 3/5/1937, IRA-MHPDM; Reifel to Collier, 3/1/1937, IRA-MHPDM; Westwood, "Memorandum to Organization Division of the U.S. Department of the Interior," 3/16/1937, IRA-MHPDM. 


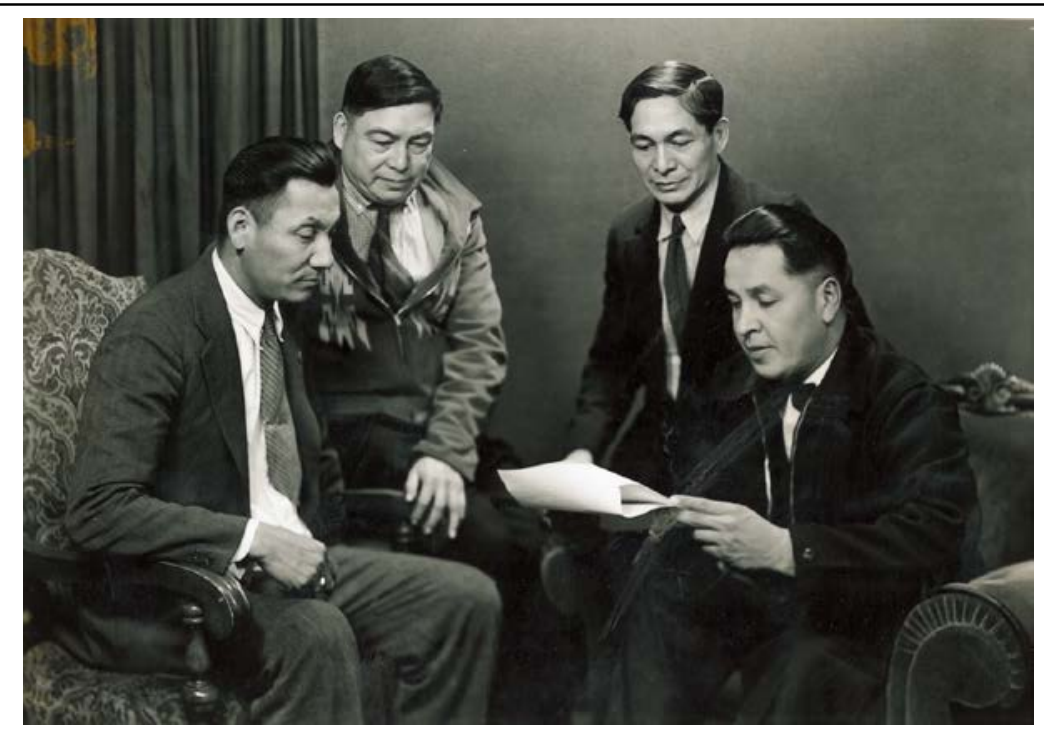

The Meskwaki Constitutional Committee - (from left) George Young Bear Sr., William Poweshiek, Horace Poweshiek, and Ed Davenport - spent over three years drafting and revising the document that still governs their tribe today. Photo (ca. 1937) from the Meskwaki Historic Preservation Department and Museum, Meskwaki Settlement.

As it became increasingly clear that the tribe was on the verge of a new system of self-governance, several issues arose regarding the constitution's form and content. Perhaps the most contentious disagreement among tribal members focused on the redistribution of settlement land. Although the tribe's communal use system had sufficed in the settlement's earliest years, by the early twentieth century, it created "wide variances in land distribution [where] a few families had as much as 60 acres while others had only enough for a homestead and garden." 100 Some Meskwaki supported allowing the council to reassign lands under the constitution in order to share the settlement more equally. That proposal met resistance from those claiming larger tracts of land, as they often rented or share-cropped their plots to other tribal members, making land an especially important Depression-era issue. ${ }^{101}$

100. Daubenmier, Meskwaki and Anthropologists, 30, 43; Grant, "The Indian." 101. Westwood, "Memorandum for Mr. Collier." 
Land remained at the center of Meskwaki politics, but whereas it had previously been a unifying buffer between the tribe and external forces, by the 1930s it was also a point of internal discord. The committee searched for a politically balanced land reform process that would ameliorate the issue without alienating enough Meskwaki to endanger the constitution. Its final version recognized extant land assignments but empowered the tribal council to reassign settlement lands under certain circumstances. Despite this compromise, the provision continued to fuel opposition to the constitution and would, in part, nearly stymie its ratification. ${ }^{102}$

Tribal citizenship was another major issue, and it, too, focused on concerns over land and tribal resources. Although the tribe remained composed almost entirely of full-blooded Meskwaki, by the mid-1930s some had married or had children with members of other tribes. ${ }^{103}$ Meskwaki Sam Slick argued to Superintendent Nelson that tribal "children should be enrolled with the father," as was customary. If the tribe adopted "just anyone," Slick argued, there would develop "such a mix-up" that people would cease to regard "real" Meskwaki. As Indians repeatedly intermarried with members of other tribes, he complained, they occupied Meskwaki land via the inheritance system. ${ }^{104}$ Again attempting to placate those on both sides of this hotly contested issue, the final constitution continued the patriarchal adoption

102. Daubenmier, Meskwaki and Anthropologists, 43-46; D'Arcy McNickle, "Memorandum to Mr. Harper, Re: Sac and Fox Indians, Tama, Iowa," 12/30/1936, IRA-MHPDM; Westwood, "Memorandum to Mr. Collier." See also Meskwaki Constitution, art. X, sec. 1 and art. XI.

103. Westwood, "Memorandum for Mr. Collier," notes that virtually no intermarriage occurred between whites and Meskwaki, but some tribal members married members of other Native tribes, "particularly [the] Winnebago and Potawatomi."

104. Daubenmier, Meskwaki and Anthropologists, 43-46. This issue also arose in 1931 when "the question came up as to who should be enrolled" following tribal intermarriages. To solve the issue, the "Indian Office told the [Meskwaki] to get together and decide for themselves; the decision was that the children should follow the Father - a mother marrying outside the tribe lost her rights." See "Minutes, January 8, 1935," folder "749 Community Meetings-Minutes of Meetings and Related Correspondence"; and "Memo Re. Sac and Fox Indians of Iowa: Washington, Feb. 4, 1931," in folder "771 Charities and Benevolences Rations (Food and Clothing), Misc. Correspondence, 1931-1933," both in box 293, NARAGL. See also Meskwaki Constitution, art. II. 
system preferred by Slick but also allowed the tribal council to formally adopt children of mixed Meskwaki lineage in some cases.

The committee struggled throughout 1937 to gain support for the document. They had attempted to craft a constitution that was both effective and politically palatable. The constitution reduced the minimum age for a seat on the tribal council to 25 and opened it to females. Some tribal members viewed both of these changes as controversial deviations from established custom. (Although women had long played an integral role in tribal politics, they had not previously been allowed to hold a seat on the council.) Additionally, under reorganization, many duties that had once been left to the chief's council, "such as representing the tribe in negotiations with the government and resolving disputes among its members," would be transferred to the new, elected council. ${ }^{105}$

Contention also arose because some tribal members remained unsure of the IRA's potential consequences. The committee had numerous meetings throughout 1937 with agency representatives as drafts of the document made the rounds through the OIA. Federal officials offered various, although generally slight, changes. Many Meskwaki remained unclear about the constitution's provisions. In February one asked Charlotte Westwood, a federal official close to the committee, "for a statement of what a constitution is and the purposes of the proposed tribal constitution." Westwood took the request seriously because she felt that some tribal members did "not understand the purpose or meaning of [re]organization." 106 Although some Meskwaki might have been unclear as to some nuanced legal language encapsulated in the document, virtually all saw that it would shift tribal governance and power dynamics. By November 1937, the fate of the pending constitution was far from assured. But the time had arrived for the ratification election.

Four years of political turmoil surrounded the IRA, leading to a dramatic election late in 1937. The constitution had received its final OIA approval in early autumn, after which the agency set the election date and forwarded 200 copies to tribal members

105. Daubenmier, Meskwaki and Anthropologists, 45; Meskwaki Constitution, art. IV and art. X, sec. 3-4.

106. Westwood to Zimmerman, 2/20/1937, IRA-MHPDM. 
for final clarification of its provisions and implications. With the sovereign decision to restructure their government and build a new political future for their community before them, tribal members cast their ballots. On November 13, with more than double the previous election's turnout, the tribe ratified the document by an excruciatingly narrow vote of 80 to 78. Assistant Secretary of the Interior Oscar L. Chapman approved it five weeks later, officially restructuring the Meskwaki government under the Indian Reorganization Act. ${ }^{107}$

THE MESKWAKI NATION continues to be governed under the 1937 constitution. It established an elected council of seven tribal members who carry legal authority over matters of tribal membership, taxation, education, healthcare, land assignments, and relations between the state and federal governments. ${ }^{108} \mathrm{But}$ the constitution has never existed without controversy. Its opponents immediately attempted to overturn its ratification. John Tataposh, for example, wrote to President Roosevelt, arguing that because the settlement was "communally owned by the [tribe], [and] purchased with their ancestors' own money," every tribal member had "a right of ownership of the land ... to the disposal of our affairs as he sees fit." The IRA and its constitution, he asserted, should not be applicable on the settlement, and tribal governance should occur exclusively on Meskwaki terms. ${ }^{109}$ To make his case, Tataposh drew on his tribe's history. Because of the settlement's anomalous status in the decades before 1896, the Meskwaki had experienced an unparalleled level of political autonomy during an era of land dispossession and sovereign suppression. The tribe's involvement with the OIA after that time, leading up to the battles over reorganization in the 1930s, mirrored that of Native nations across the country, with some key distinctions based on its unique land ownership. Meskwaki tribal members struggled throughout to maintain their sovereignty as the

107. Zimmerman to Nelson, 9/22/1937, IRA-MHPDM; Nelson to Collier, 9/30/ 1937, IRA-MHPDM; Daubenmier, Meskwaki and Anthropologists, 45; Buffalo, "Historical Overview," 25.

108. Brown, "Social History," 81.

109. John Tataposh to Franklin Delano Roosevelt, 2/2/1938, IRA-MHPDM. 
pressures of OIA interference and internal partisanship tore at their political fabric.

In the twenty-first century, members of the Meskwaki Nation continue to draw on this history. The settlement boundary, as in many indigenous communities, still marks an autonomous Meskwaki space that "reinforce[s] tribal cultures and identities." 110 Daily life requires tribal members to transcend those boundaries, and they continue to assert their sovereignty by working across the American political system. The Meskwaki Nation uses assets like gaming revenues to bolster education and healthcare and to purchase additional land. Yet in some ways, generations-old political disagreements remain. The tribe has attempted to repeal or dramatically reform its constitution approximately once per decade over the past 75 years, most recently in 2004. ${ }^{111}$ Moreover, not long ago a Meskwaki tribal judge referred to the constitution as "flawed and biased from the start" because, in her view, the federal government had forced the IRA onto her community. ${ }^{112}$ Some might see her statement, or the highly publicized turbulence surrounding the 2003 Meskwaki Casino shutdown as reminiscent of the discordant politics of the early twentieth century. ${ }^{113}$

As the longer arc of Meskwaki history reveals, however, the conversation between tribal members and surrounding governments-as well as among themselves-over the meaning and form of Meskwaki sovereignty has been ongoing since at least the mid-nineteenth century. Because of the tribe's ownership of the settlement, the Meskwaki story is in many ways unique. But its core characteristics are not. The Indian policies of the late nineteenth and early twentieth centuries are too often remembered as being overwhelming for American Indian tribes. Such histories cast Native peoples as unable to defend themselves, their resources, or their rights against the pressures of assimilation and

110. Rand, “Primary Sources," 136-37.

111. Buffalo, "Historical Overview," i, 29-47, details the seven major attempts $(1938,1948,1962,1978,1986,1994$, and 2004) to reform the tribal constitution.

112. Theresa Essman Mahoney, "Practical Tips for Advocates of Indian Children: A Tribal Perspective" (slideshow presented at the 2011 Iowa State Bar Association's Juvenile Law Seminar, 5/6/2011), 3-4.

113. "Appeals Court Sides with NIGC on Casino Shutdown," Indianz.com, 8/28/ 2003, www.indianz.com/News/archives/001047.asp, accessed 7/13/2012. 
allotment. Looking to the Meskwaki Nation reminds us that while American Indians were indeed affected by the oppressive policies of the time, tribal members used their resources, both physical and political, to understand and engage the changing political world around them. Even in moments of weakness relative to the OIA, the Meskwaki people remained active and searched for strategies to regain local control. They acted opportunistically to defend their right to self-governance, because their interest rarely, if ever, strayed far from protecting and affirming their tribal sovereignty. 